\title{
Synthesis, Vibrational Spectra and Normal Coordinate Analysis of Cesium-Hexathiohypodiphosphate $\mathrm{Cs}_{4} \mathbf{P}_{2} \mathbf{S}_{6}$
}

\author{
S. J. Cyvin and B. N. Cyvin \\ Institutt for fysikalsk kjemi, Norges tekniske høgskole, N-7034 Trondheim-NTH, Norway \\ C. Wibbelmann \\ Department of Chemistry, University of Aberdeen, Old Aberdeen, AB 92 UE, Scotland \\ R. Becker, W. Brockner, and M. Parensen \\ Institut für Anorganische Chemie, Technische Universität Clausthal, \\ D-3392 Clausthal-Zellerfeld, FRG
}

Z. Naturforsch. 40 a, 709-713 (1985); received May 3, 1985

\begin{abstract}
The title compound has been prepared by elemental synthesis at high temperatures and also by reaction of $\mathrm{Na}_{4} \mathrm{P}_{2} \mathrm{~S}_{6} \cdot 6 \mathrm{H}_{2} \mathrm{O}$ with $\mathrm{CsCl}$ in aqueous solution. Both reaction products have closely related vibrational spectra which are assigned on the basis of a $\mathrm{P}_{2} \mathrm{~S}_{6}^{4-}$ anion with perturbed $\mathrm{D}_{3 \mathrm{~d}}$ symmetry. A normal coordinate analysis has been performed using a force field with 4 initial force constants. The refined force field, potential energy distribution (PED), mean amplitudes of vibration and Coriolis coupling constants are given.
\end{abstract}

Keywords: Cesiumhexathiohypodiphosphate, $\mathrm{Cs}_{4} \mathrm{P}_{2} \mathrm{~S}_{6}$, Vibration Spectra,

Normal Coordinate Analysis

\section{Introduction}

Since their rediscovery in the mid-sixties $[1-3]$ metal thiohypodiphosphates, especially those with transition metal cations, have shown great prospect for future development [3-13] because of their interesting chemical and physical properties. Most notable are their chemical inertness and their ability to intercalate lithium [8] and metallocenes [10, 14, 15]. Some of them are also noted for their nonlinear electrical and optical properties.

Common to all thiohypodiphosphates is the spectroscopically relevant $\mathrm{P}_{2} \mathrm{~S}_{6}^{4-}$ complex anion in which two terminal $\mathrm{PS}_{3}$-groups are joined through a P-P-bond. In recent publications contradictory assignments of the vibrational frequencies of thiohypodiphosphates have been put forward $[1,13$, 15-18]. A probable cause for these discrepancies could be seen in the existence of other thiophosphorous compounds which are formed in subsequent solid state reactions during annealing, laser irradiation or even self storage [19].

The extent of $\mathrm{H}_{2} \mathrm{O}-\mathrm{P}_{2} \mathrm{~S}_{6}^{4-}$ interactions like protonation and hydrolysis in crystal water containing

Reprint requests to Prof. Dr. W. Brockner, Institut für Anorganische Chemie, Technische Universität Clausthal, D-3392 Clausthal-Zellerfeld, FRG. salts and aqueous solutions is not clear. We have obtained $\mathrm{Cs}_{4} \mathrm{P}_{2} \mathrm{~S}_{6}$ in two ways: (i) by synthesis from the elements at high temperatures, (ii) by reaction of $\mathrm{Na}_{4} \mathrm{P}_{2} \mathrm{~S}_{6} \cdot 6 \mathrm{H}_{2} \mathrm{O}$ with $\mathrm{CsCl}$ in aqueous solution. The vibrational spectra of both products are nearly identical.

\section{Experimental}

The high temperature synthesis of $\mathrm{Cs}_{4} \mathrm{P}_{2} \mathrm{~S}_{6}$ was carried out in quartz glass crucibles in evacuated ampoules made of the same material, using a stoichiometrical mixture of the high purity elements. Cesium and the $\mathrm{P} / \mathrm{S}$ mixture were kept in separate parts of the ampoule so that the formation reaction occurred in the gas phase during slow warm up $(8-10 \mathrm{~K} / \mathrm{h})$. The cell was then kept at $1020 \mathrm{~K}$ for 12 hours and afterwards left to cool in the switched off furnace. Light yellow $\mathrm{Cs}_{4} \mathrm{P}_{2} \mathrm{~S}_{6}$ of spectroscopic purity was formed at the outer quartz wall.

From a saturated aqueous solution of $\mathrm{Na}_{4} \mathrm{P}_{2} \mathrm{~S}_{6}$ - $6 \mathrm{H}_{2} \mathrm{O}$ (synthesized according to Falius [1], twice recrystallized from water) and $\mathrm{CsCl}(10 \%$ excess $\mathrm{CsCl}$ relative to $\mathrm{Na}$ ) at $310 \mathrm{~K}$, large colorless plateletts of $\mathrm{Cs}_{4} \mathrm{P}_{2} \mathrm{~S}_{6}$ are precipitated upon cooling to 
room temperature. These were then twice recrystallized from diluted $\mathrm{CsCl}$ solution.

Raman spectra were recorded using a Coderg $\mathrm{PH} 1$ spectrometer and $647.1 \mathrm{~nm} / 500 \mathrm{~mW}$ excitation from a Spectra Physics Krypton-ion-laser, model $165 / 01$. The scattered light was collected perpendicular to the incident beam. The FIR spectra were obtained from $\mathrm{Cs}_{4} \mathrm{P}_{2} \mathrm{~S}_{6}$-PE pellets with a Bruker IFS $113 v$ FT spectrometer.

\section{Results}

The vibrational frequencies $\left(\mathrm{cm}^{-1}\right)$ of our $\mathrm{Cs}_{4} \mathrm{P}_{2} \mathrm{~S}_{6}$ samples with their intensities and assignment are compared in Table 1 with data from literature $\left(\mathrm{Na}_{4} \mathrm{P}_{2} \mathrm{~S}_{6} \cdot 6 \mathrm{H}_{2} \mathrm{O}[1,15]\right)$. Polarization data were obtained from phosphorous-sulfide $/ \mathrm{Cs}_{4} \mathrm{P}_{2} \mathrm{~S}_{6}$-melts [19]. The IR/FIR (a) and Raman (b) spectrum of $\mathrm{Cs}_{4} \mathrm{P}_{2} \mathrm{~S}_{6}$ are shown in Figure 1 .

\section{Discussion and Normal Coordinate Analysis}

In hexathiohypodiphosphates the $\mathrm{P}_{2} \mathrm{~S}_{6}^{4-}$ complex anion is the spectroscopically relevant unit, which is

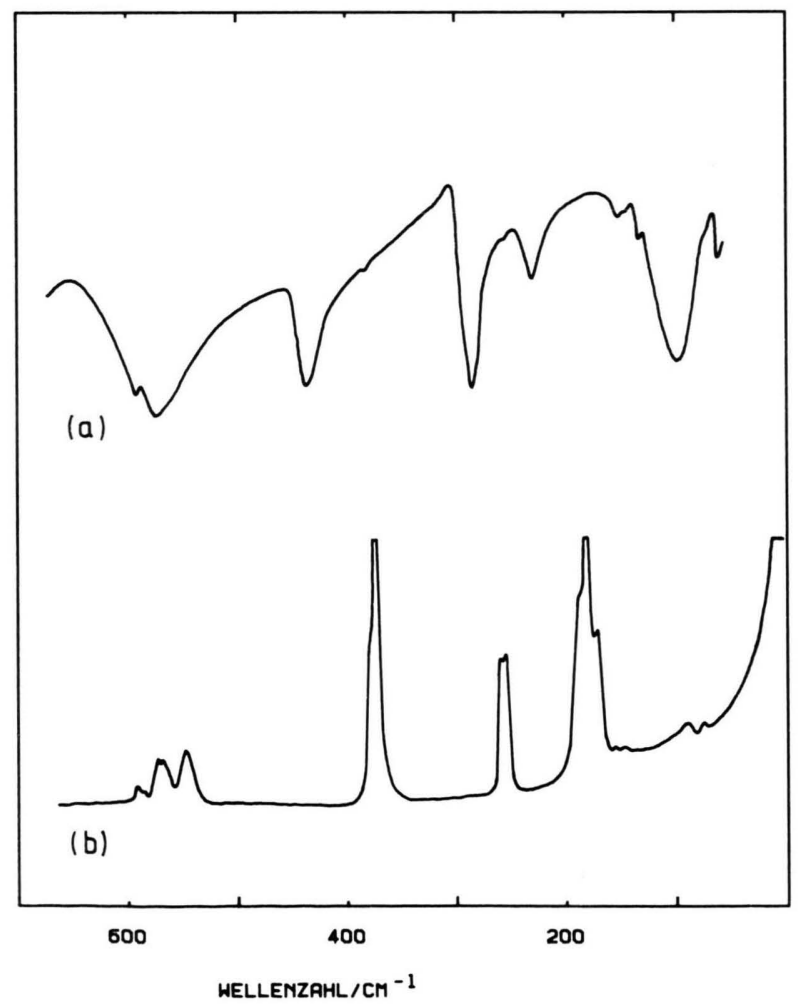

Fig. 1. IR/FIR (a) and Raman (b) spectrum of solid $\mathrm{Cs}_{4} \mathrm{P}_{2} \mathrm{~S}_{6}$ at room temperature. isoelectronic with $\mathrm{Si}_{2} \mathrm{Cl}_{6}$ and has $\mathrm{D}_{3 \mathrm{~d}}$ symmetry. The normal modes of vibration are distributed among the symmetry species of the $D_{3 \mathrm{~d}}$ point group according to [20]

$$
\begin{aligned}
\Gamma_{\mathrm{vib}}=3 \mathrm{~A}_{1 \mathrm{~g}}(\mathrm{RE}) & +\mathrm{A}_{1 \mathrm{u}}(\mathrm{ia})+2 \mathrm{~A}_{2 \mathrm{u}}(\mathrm{IR}) \\
& +3 \mathrm{E}_{\mathrm{g}}(\mathrm{RE})+3 \mathrm{E}_{\mathrm{u}}(\mathrm{IR}) .
\end{aligned}
$$

$2 A_{1 g}+A_{2 u}+E_{g}+E_{u}$ are stretching vibrations, the remaining ones are deformations. The mutual exclusion rule is valid.

Our assignment of the $\mathrm{P}_{2} \mathrm{~S}_{6}^{4-}$ vibration frequencies (Table 1) is supported by polarization data obtained from cold saturated $\mathrm{Na}_{4} \mathrm{P}_{2} \mathrm{~S}_{6} \cdot 6 \mathrm{H}_{2} \mathrm{O}$ solutions ("free" $\mathrm{P}_{2} \mathrm{~S}_{6}^{4-}$ anion [17]) and $\mathrm{Cs}_{4} \mathrm{P}_{2} \mathrm{~S}_{6}$ melts [19]. Our experimental data and their assignment are in agreement with those published by Bürger and Falius [1], Kliche [13] and Mercier et al. [16] but opposed to those reported by Sourisseau et al. [15]. The differing vibrational frequencies are plausible when the synergetic formation reactions and possible equilibrations between different thiophosphates $[19,21]$ are considered. Of these,

and

$$
\begin{aligned}
& \mathrm{P}_{2} \mathrm{~S}_{6}^{4-}+\mathrm{S} \rightleftharpoons \mathrm{P}_{2} \mathrm{~S}_{6}^{2-}+\mathrm{S}^{2-} \\
& \mathrm{P}_{2} \mathrm{~S}_{6}^{2-} \stackrel{\mathrm{S}^{2-}}{\rightleftharpoons} \mathrm{P}_{2} \mathrm{~S}_{7}^{4-} \stackrel{\mathrm{S}^{2-}}{\rightleftharpoons} 2 \mathrm{PS}_{4}^{3-}
\end{aligned}
$$

play a major role. It can be shown $[19,21]$ that alkali hexathiohypodiphosphates react in the solid state at room temperature (faster at higher temperatures) corresponding to the equilibria mentioned above. A series of vibrational frequencies found in [15] can be assigned accordingly to the anions $\mathrm{P}_{2} \mathrm{~S}_{6}^{2-}$ and $\mathrm{PS}_{4}^{3-}$ (cf. Table 1).

The Wilson-GF-matrix method [20] was used to model the vibrational behavior of the $\mathrm{P}_{2} \mathrm{~S}_{6}^{4-}$ anion. Bürger and Falius proceeded in the same way using Fadini's "Kopplungsstufen" method [22] to solve the secular equations whereas we used a different iteration method [23].

The symmetry coordinates of the staggered $\mathrm{X}_{2} \mathrm{Y}_{6}$ (symmetry $\mathrm{D}_{3 \mathrm{~d}}$ ) model are easily constructed in the usual way [20]. The set employed here is practically identical with the one published elsewhere [24], with the exception that the redundancies were handled in a simpler way. The situation is explained by Table 2, where the types of valence coordinates used in the appropriate symmetry-adapted combination are specified. 
Table 1. Vibrational frequencies $\left(\mathrm{cm}^{-1}\right)$ of $\mathrm{Cs}_{4} \mathrm{P}_{2} \mathrm{~S}_{6}$ with their intensity and polarization data and assignment compared with literature data $(\mathrm{s}=$ strong, $\mathrm{m}=$ medium, $\mathrm{w}=$ weak, $\mathrm{v}=$ very, $\mathrm{sh}=$ shoulder, $\mathrm{p}=$ polarized $)$.

\begin{tabular}{|c|c|c|c|c|c|c|c|}
\hline \multicolumn{2}{|c|}{$\mathrm{Na}_{4} \mathrm{P}_{2} \mathrm{~S}_{6} \cdot 6 \mathrm{H}_{2} \mathrm{O}[1]$} & \multicolumn{2}{|l|}{$\mathrm{Cs}_{4} \mathrm{P}_{2} \mathrm{~S}_{6}$} & \multirow{2}{*}{$\begin{array}{l}\text { Assign- } \\
\text { ment } \\
\mathrm{D}_{3 \mathrm{~d}}\end{array}$} & \multicolumn{2}{|c|}{$\mathrm{Na}_{4} \mathrm{P}_{2} \mathrm{~S}_{6} \cdot 6 \mathrm{H}_{2} \mathrm{O}[15]$} & \multirow{2}{*}{$\begin{array}{l}\text { Assign- } \\
\text { ment [15] } \\
\mathrm{D}_{3 \mathrm{~d}}\end{array}$} \\
\hline Raman & FIR/IR & Raman & FIR/IR & & Raman & FIR/IR & \\
\hline & $87 w$ & $86 \mathrm{~m}$ & $\left.\begin{array}{c}97 \mathrm{~s} \\
130 \mathrm{w} \\
152 \mathrm{w}\end{array}\right\}^{\mathrm{e}}$ & $\begin{array}{l}\text { Lattice } \\
\text { vibr. } \\
v_{12}\left(\mathrm{E}_{\mathrm{u}}\right)\end{array}$ & $\begin{array}{l}21 \mathrm{~s}, 33 \mathrm{vs}, 44 \mathrm{vw} \\
59 \mathrm{w}, 67 \mathrm{w}, 90 \mathrm{vw} \\
100 \mathrm{vw}\end{array}$ & $\begin{array}{l}29 \mathrm{vw}, 40 \mathrm{vw} \\
83 \mathrm{vw} \\
96 \mathrm{vw}\end{array}$ & $v_{9}\left(\mathrm{E}_{\mathrm{u}}\right)$ \\
\hline $169 \mathrm{w}$ & & $\left.\begin{array}{l}152 \mathrm{vw} \\
156 \mathrm{vw}\end{array}\right\}^{\mathrm{e}}$ & & $v_{\mathrm{q}}\left(\mathrm{E}_{\mathrm{g}}\right)$ & $158 \mathrm{~m}^{\mathrm{a}}$ & $154 \mathrm{w}$ & $v_{2}\left(\mathrm{~A}_{1 \mathrm{~g}}\right)$ \\
\hline $197 \mathrm{~m}$ & & 183 vs & & $v_{3}\left(\mathrm{~A}_{1 \mathrm{~g}}\right)$ & $\left.\begin{array}{l}178 \mathrm{~m}^{\mathrm{a}} \\
200 \mathrm{~s}\end{array}\right\}$ & $\left.\begin{array}{l}182 \mathrm{vw} \\
205 \mathrm{vw}\end{array}\right\}$ & $v_{12}\left(\mathrm{E}_{\mathrm{g}}\right)$ \\
\hline & $243 \mathrm{~m}$ & & $227 \mathrm{~m}$ & $v_{11}\left(\mathrm{E}_{\mathrm{u}}\right)$ & $222 \mathrm{~m}^{\mathrm{b}}$ & $\begin{array}{l}220 \mathrm{vw} \\
240 \mathrm{~m}\end{array}$ & $v_{8}\left(\mathrm{E}_{\mathrm{u}}\right)$ \\
\hline $259 \mathrm{~s}$ & & $\left.\begin{array}{l}259 \mathrm{~s} \\
263 \mathrm{~s}\end{array}\right\}^{\mathrm{e}}$ & & $v_{8}\left(\mathrm{E}_{\mathrm{g}}\right)$ & $264 s$ & $265 \mathrm{vw}$ & $v_{11}\left(\mathrm{E}_{\mathrm{g}}\right)$ \\
\hline 374 vs & $\begin{array}{l}302 \mathrm{~s} \\
380 \mathrm{vw}\end{array}$ & 378 vs, p & $284 \mathrm{~s}$ & $\begin{array}{l}v_{6}\left(\mathrm{~A}_{2 \mathrm{u}}\right) \\
v_{2}\left(\mathrm{~A}_{1 \mathrm{~g}}\right)\end{array}$ & $\begin{array}{l}378 \mathrm{vs} \\
408 \mathrm{vw}^{\mathrm{c}}\end{array}$ & $\begin{array}{l}300 \mathrm{~m} \\
399 \mathrm{vw}\end{array}$ & $\begin{array}{l}v_{6}\left(\mathrm{~A}_{2 \mathrm{u}}\right) \\
v_{1}\left(\mathrm{~A}_{1 \mathrm{~g}}\right)\end{array}$ \\
\hline & $444 \mathrm{~s}$ & & $440 \mathrm{~s}$ & $v_{5}\left(\mathrm{~A}_{2 \mathrm{u}}\right)$ & $\begin{array}{l}439 \mathrm{vw} \\
475 \mathrm{vw}^{\mathrm{d}}\end{array}$ & $443 \mathrm{~m}$ & $v_{3}\left(\mathrm{~A}_{1 \mathrm{~g}}\right)$ \\
\hline & $\begin{array}{l}489 \mathrm{vw} \\
528 \mathrm{vw}\end{array}$ & & & & $482 \mathrm{vw}^{\mathrm{d}}$ & $\left.\begin{array}{l}479 \mathrm{w} \\
525 \mathrm{w}\end{array}\right\}$ & $\begin{array}{l}\text { Libration } \\
\left(\mathrm{H}_{2} \mathrm{O}\right)\end{array}$ \\
\hline $\begin{array}{l}557 \mathrm{~s} \\
578 \mathrm{~m}\end{array}$ & & $\left.\begin{array}{l}553 \mathrm{~s}, \mathrm{p} \\
572 \mathrm{~m}\end{array}\right\}$ & & $\begin{array}{l}v_{1}\left(\mathrm{~A}_{1 \mathrm{~g}}\right) \\
v_{7}\left(\mathrm{E}_{\mathrm{g}}\right)\end{array}$ & $557 \mathrm{~s}$ & & $v_{10}\left(\mathrm{E}_{\mathrm{g}}\right)$ \\
\hline & $\begin{array}{l}585 \mathrm{~s} \\
606 \mathrm{sh}\end{array}$ & $588 w^{e}$ & $\left.\left.\begin{array}{l}578 \mathrm{~m} \\
598 \mathrm{~s}\end{array}\right\}\right\}^{\mathrm{e}}$ & $v_{10}\left(\mathrm{E}_{\mathrm{u}}\right)$ & $580 \mathrm{~m}$ & $\begin{array}{l}582 \text { vs } \\
592 \mathrm{sh} \\
606 \mathrm{~s}\end{array}$ & $v_{7}\left(\mathrm{E}_{\mathrm{u}}\right)$ \\
\hline
\end{tabular}

${ }^{\text {a }} \mathrm{P}_{2} \mathrm{~S}_{6}^{2-}$ wing; ${ }^{\mathrm{b}} \mathrm{PS}_{4}^{3-}$ and/or $\mathrm{S}$ and Polysulfide bands, respectively; ${ }^{\mathrm{c}} \mathrm{PS}_{4}^{3-}$ and/or $\mathrm{P}_{2} \mathrm{~S}_{6}^{2-}$ mode; ${ }^{\mathrm{d}} \mathrm{S}$ and/or Polysulfide fundamentals; ${ }^{\mathrm{e}}$ the mean values have been used for calculations.

Table 2. Types of valence coordinates for the staggered $\mathrm{X}_{2} \mathrm{Y}_{6}$ molecular model with $\mathrm{D}_{3 \mathrm{~d}}$ symmetry.

\begin{tabular}{llll}
\hline Species & \multicolumn{3}{l}{ Coordinate types $^{\mathrm{a}}$} \\
\hline $\mathrm{A}_{1 \mathrm{~g}}$ & $d$ & $r$ & $\alpha$ \\
$\mathrm{E}_{\mathrm{g}}$ & $r$ & $\alpha$ & $\beta$ \\
$\mathrm{A}_{1 \mathrm{u}}$ & $\tau$ & & \\
$\mathrm{A}_{2 \mathrm{u}}$ & $r$ & $\beta$ & \\
$\mathrm{E}_{\mathrm{u}}$ & $r$ & $\alpha$ & $\beta$ \\
\hline
\end{tabular}

a $d$ : P-P stretch; $r$ : P-S stretch; $\alpha$ : SPS bend; $\beta$ : PSS bend; $\tau$ : torsion.

The structure parameters were estimated from related compounds as $2.02 \AA$ and $2.20 \AA$ for the $\mathrm{P}-\mathrm{S}$ and $\mathrm{P}-\mathrm{P}$ bond lengths, respectively. They are in reasonable agreement with the recent data of $\mathrm{Pb}_{2} \mathrm{P}_{2} \mathrm{~S}_{6}$ [12]. The angles were assumed as tetrahedral.
The initial force field in form of a diagonal $F$ matrix was set up using the following force constants (in mdyn $/ \AA$ ): $f_{(\mathrm{P}-\mathrm{S})}=2.40, f_{(\mathrm{P}-\mathrm{P})}=1.40, f_{(\mathrm{SPS})}$ $=f_{\text {(SPP) }}=0.25$ and $f_{\tau}=0.1$.

Already this simple initial force field yielded a quite good agreement with the experimental data (cf. Table 1,3). The value obtained for the inactive $\mathrm{A}_{1 \mathrm{u}}$ torsion mode at $109 \mathrm{~cm}^{-1}$ seems reasonable. In Table 3 calculated frequencies $\left(\mathrm{cm}^{-1}\right)$ and the potential energy distribution (PED) data are listed [25].

The final force field in terms of symmetry coordinates was fitted exactly to the experimental frequencies and is given in Table 4. The PED values (Table 3) show that almost all Raman active fundamental modes of vibration are strongly coupled.

The conventional description of the normal modes of vibration is unsatisfactory. Especially the 
Table 3. Calculated frequencies $\left(\mathrm{cm}^{-1}\right)$ of the $\mathrm{P}_{2} \mathrm{~S}_{6}^{4-}$ complex anion and the potential energy distribution (PED).

\begin{tabular}{llllll}
\hline \multicolumn{2}{l}{ Species } & $a$ & $b$ & $c$ & PED * \\
\hline $\mathrm{A}_{1 \mathrm{~g}}$ & $v_{1}$ & 553 & 558 & 553 & $61 d+44 r+41 \alpha$ \\
& $v_{2}$ & 378 & 316 & 378 & $59 r$ \\
& $v_{3}$ & 183 & 132 & 183 & $49 \alpha+31 d$ \\
$\mathrm{E}_{\mathrm{g}}$ & $v_{7}$ & 580 & 635 & 580 & $80 r+24 \beta$ \\
& $v_{8}$ & 261 & 235 & 261 & $29 \beta+25 \alpha+21 r$ \\
& $v_{9}$ & 154 & 183 & 154 & $74 \alpha+54 \beta$ \\
$\mathrm{A}_{1 \mathrm{u}}$ & $v_{4}$ & - & 109 & $109 * *$ & $100 \tau$ \\
$\mathrm{A}_{2 \mathrm{u}}$ & $v_{5}$ & 440 & 452 & 440 & $79 r+29 \beta$ \\
& $v_{6}$ & 284 & 266 & 284 & $72 \beta+22 r$ \\
$\mathrm{E}_{\mathrm{u}}$ & $v_{10}$ & 588 & 586 & 588 & $84 r$ \\
& $v_{11}$ & 227 & 244 & 227 & $90 \alpha$ \\
& $v_{12}$ & 141 & 128 & 141 & $101 \beta$ \\
\hline
\end{tabular}

$a$ : experimental $\mathrm{Cs}_{4} \mathrm{P}_{2} \mathrm{~S}_{6}$ frequencies, for the $\mathrm{E}_{\mathrm{g}}$ and $\mathrm{E}_{\mathrm{u}}$ frequencies mean values have been used; $b$ : calculated frequencies from the initial force field; $c$ : calculated from the final force field.

* Terms below 20 are omitted.

** Calculated value from the initial force field.

Table 4. Final symmetry force constants (mdyn/ $\AA$ ) for $\mathrm{P}_{2} \mathrm{~S}_{6}^{4-}$.

\begin{tabular}{llllllrrrr}
\hline $\mathrm{A}_{1 \mathrm{~g}}$ & 3.08 & & & & & $\mathrm{E}_{\mathrm{g}}$ & 2.27 & & \\
& 0.34 & 2.03 & & & & & 0.10 & 0.22 & \\
& 0.12 & -0.33 & 0.84 & & & 0.09 & -0.05 & 0.23 \\
\hline $\mathrm{A}_{1 \mathrm{u}}$ & 0.10 & $\mathrm{~A}_{2 \mathrm{u}}$ & 2.39 & & $\mathrm{E}_{\mathrm{u}}$ & 2.37 & & & \\
& & & 0.09 & 0.57 & & 0.04 & 0.31 & & \\
& & & & & 0.01 & -0.05 & 0.33 & \\
& & & & & & & & & \\
\hline
\end{tabular}

$v_{1}$ and $v_{2}$ modes cannot be attributed to pure $\mathrm{P}-\mathrm{P}$ resp. $\mathrm{PS}_{3}$ stretchings. This has already been pointed out by Bürger and Falius [1]. The same is true for the assignment of the $\mathrm{P}_{2} \mathrm{O}_{6}^{4-}$ frequencies [26].

The final force field (Table 4) was used to calculate different "molecular" constants of $\mathrm{P}_{2} \mathrm{~S}_{6}^{4-}$ [25].

[1] H. Falius, Z. anorg. allg. Chem. 356, 189 (1968); H. Bürger and H. Falius, Z. anorg. allg. Chem. 363, 24 (1968).

[2] W. Klingen, Dissertation Universität Hohenheim, 1969; and W. Klingen, R. Ott, and H. Hahn, Z. anorg. allg. Chem. 396, 271 (1973).

[3] M. S. Whittingham and A. J. Jacobson, Intercalation Chemistry, Academic Press Inc., London 1982, p. $267-283$.

[4] B. E. Taylor, J. Steger, and A. Wold, J. Solid State Chem. 7,461 (1973).

[5] G. Dittmar and H. Schäfer, Z. Naturforsch. 29b, 312 (1974).
Table 5. Mean amplitudes of vibration $(\AA)$ of $\mathrm{P}_{2} \mathrm{~S}_{6}^{4-}$.

\begin{tabular}{llll}
\hline Distance type $^{\text {a }}$ & \multicolumn{3}{c}{ Mean amplitude } \\
& $T=0$ & $298 \mathrm{~K}$ & $773 \mathrm{~K}$ \\
\hline $\mathrm{P}-\mathrm{S}(2.02)$ & 0.0452 & 0.0500 & 0.0692 \\
$\mathrm{P}-\mathrm{P} \quad(2.20)$ & 0.0475 & 0.0550 & 0.0781 \\
$\mathrm{~S} \ldots \mathrm{S}(3.30)$ & 0.0615 & 0.0840 & 0.1285 \\
$\mathrm{P} \ldots \mathrm{S}(3.45)$ & 0.0597 & 0.0840 & 0.1286 \\
$\mathrm{~S} \ldots \mathrm{S}(4.03)$ & 0.0796 & 0.1340 & 0.2115 \\
S ... S (5.20) & 0.0627 & 0.0885 & 0.1361 \\
\hline
\end{tabular}

a Parenthesized equilibrium distances in $\AA$.

Table 6. The most important Coriolis coupling constants of the $\mathrm{P}_{2} \mathrm{~S}_{6}^{4-}$ complex anion.

\begin{tabular}{llr}
\hline $\mathrm{E}_{\mathrm{g}} \times \mathrm{E}_{\mathrm{g}}$ & $\zeta_{7}$ & 0.837 \\
& $\zeta_{8}$ & -0.448 \\
& $\zeta_{9}$ & -0.050 \\
$\mathrm{E}_{\mathrm{u}} \times \mathrm{E}_{\mathrm{u}}$ & $\zeta_{10}$ & 0.803 \\
& $\zeta_{11}$ & -0.843 \\
& $\zeta_{12}$ & 0.039 \\
\hline
\end{tabular}

Among the Coriolis coupling constants the most important ones are the first-order constants. They are given in Table 5. In Table 6 the mean amplitudes of vibration at different temperatures are reported.

\section{Acknowledgements}

Financial support to B. N. Cyvin from the Norwegian Research Council for Science and the Humanities is gratefully acknowledged. Appreciation is expressed to Deutsche Forschungsgemeinschaft and Fonds der Chemischen Industrie for their respective support of this research.

[6] R. Nitsche, Abh. Akad. Wiss. DDR, Abt. Math., Naturwiss., Technik, Bd. 5, Berlin 1977, p. 251-259.

[7] M. I. Gurzan, A. P. Buturlakin, V. S. Gerasimenko, N. F. Korda, and V. Yu. Slivka, Sov. Phys. Solid State 19, 1794 (1977).

[8] R. Brec, D. M. Schleich, G. Ouvrard, A. Louisy, and J. Rouxel, Inorg. Chem. 18, 1814 (1979).

[9] R. Blachnik and U. Rabe, Z. anorg. allg. Chem. 462, 199 (1980).

[10] R. Clément, J. J. Girerd, and I. Morgenstern-Badarau, Inorg. Chem. 19, 2852 (1980)

[11] J. Boerio-Goates, E. Lifshitz, and H. A. Francis, Inorg. Chem. 20,3019 (1981). 
[12] R. Becker, W. Brockner, and H. Schäfer, Z. Naturforsch. 38a, 874 (1983).

[13] G. Kliche, J. Solid State Chem. 51, 118 (1984).

[14] J. P. Audiere, R. Clement, Y. Mathey, and C. Mazieres, Physica 99 B, 133 (1980).

[15] C. Sourisseau, J. P. Forgerit, and Y. Mathey, J. Solid State Chem. 49, 134 (1983).

[16] R. Mercier, J. P. Malugani, B. Fahys, J. Douglade, and G. Robert, J. Solid State Chem. 43, 151 (1982).

[17] W. Brockner and U. Pätzmann, Z. Naturforsch. 38a, 92 (1983).

[18] R. Becker, W. Brockner, and C. Wibbelmann, Z. Naturforsch. 38 a, 55 (1983).

[19] M. Parensen and R. Becker, unpublished results.

[20] E. B. Wilson, J. C. Decius, and P. C. Cross, Molecular Vibrations, McGraw-Hill Book Comp., New York 1955.
[21] R. Becker and W. Brockner, Z. Naturforsch. 39a, 1120 (1984).

[22] W. Sawodny, A. Fadini, and K. Ballein, Spectrochim. Acta 21,995 (1965).

[23] S. J. Cyvin, J. Brunvoll, B. N. Cyvin, M. Somer, and W. Brockner, Z. Naturforsch. 35a, 1062 (1980).

[24] S. J. Cyvin, I. Elvebredd, J. Brunvoll, and G. Hagen, Acta Chem. Scand. 22, 1491 (1968).

[25] S. J. Cyvin, Molecular Vibrations and Mean Square Amplitudes, Elsevier, Amsterdam 1968.

[26] H. Siebert, Anwendungen der Schwingungsspektroskopie in der Anorganischen Chemie, Springer-Verlag, Berlin 1966. 